\title{
Free carotenoid and carotenoid ester composition in native orange juices of different varieties
}

\author{
Daniele GIUfFRIDA $^{1 *}$, Paola Dugo ${ }^{2}$, Andrea SALvo ${ }^{1}$, Marcello SAITTA ${ }^{1}$, Giacomo Dugo ${ }^{1}$
}

\author{
${ }^{1}$ Univ. Messina, Dip. Sci. Alim. \\ Amb., Fac. Sci., \\ Salita Sperone 31, \\ 98166 Messina, Italy \\ dgiuffrida@unime.it \\ ${ }^{2}$ Univ. Messina, Dip. Farm.- \\ Chim., Fac. Farm., \\ Viale Annunziata, \\ 98168 - Messina, Italy
}

* Correspondence and reprints

Received 27 October 2009 Accepted 17 February 2010

Fruits, 2010 , vol. 65 , p. $277-284$ (C) 2010 Cirad/EDP Sciences All rights reserved DOI: 10.1051/fruits/2010023 www.fruits-journal.org

RESUMEN ESPAÑOL, p. 284
Free carotenoid and carotenoid ester composition in native orange juices of different varieties.

Abstract - Introduction. Among the citrus species, C. sinensis has been the most studied given its importance in terms of production and its industrial application in juices. Some of orange juice's organoleptic and functional properties, which make it an attractive product for the consumer, are due to its carotenoid composition. Xanthophylls can be found in either their free form (as the carotenes are found) or in a more stable fatty acid esterified form in the case of mono- and polyhydroxylated xanthophylls. Detection of adulteration of orange juices is of concern to consumers, regulatory agencies and citrus processing industries, and the study of carotenoid ester composition has been proposed to evaluate fruit products' authenticity. In this study, we report on the native (carotenoid esters and free carotenoids) carotenoid profile of orange juices of eight different varieties. Materials and methods. Monovarietal fresh orange juices were obtained from squeezing mid-season oranges (Citrus sinensis varieties: Bionda, Brasiliana, Moro, Ovale, Sanguinello, Tarocco, Valence and Washington) cultivated and supplied by a local producer. After the extraction of the carotenoids from the samples, the analyses were carried out by HPLC-DAD-APCI-MS. Results and discussion. The results showed that, in the juices studied, the xanthophylls were mostly esterified ( $93 \%$ of the total carotenoid mean content). The different varieties investigated showed variations in their carotenoid contents. The total carotenoid contents ranged from $2.42 \mu \mathrm{g} \cdot \mathrm{g}^{-\mathrm{P}}$ in the Washington variety to $15.8 \mu \mathrm{g} \cdot \mathrm{g}^{-1}$ in the Valencia variety. Among the monoesters, the Valencia variety showed the highest violaxanthin ester amounts (61\%), the Brasiliana variety showed the highest $\beta$-cryptoxanthin ester content $(86.9 \%)$ and the Tarocco variety had the highest luteoxanthin ester amount $(75.7 \%)$. Moreover, in general, in the Brasiliana, Ovale, Sanguinello, Valencia and Washington varieties, the monoester contents were higher than the diesters, whereas in the Bionda, Moro and Tarocco varieties the opposite was determined. To the best of our knowledge, this is the first time that this analytical approach has been applied to characterising, both qualitatively and quantitatively, the whole carotenoid pattern (carotenoid esters and free carotenoids) in orange juices from the Bionda, Brasiliana, Moro, Ovale, Sanguinello, Tarocco, Valence and Washington varieties. This contribution could also be used to establish authenticity markers among orange varieties that could potentially be used to prevent adulteration.

Italy / Citrus sinensis / fruits / orange juice / esters / carotenoids / xanthophylls / chromatography

Composition en caroténoïdes libres et esters de caroténoïdes dans le jus d'orange de différentes variétés.

Résumé - Introduction. Parmi les espèces du genre Citrus, C. sinensis a été la plus étudiée du fait de son importance en termes de production et de son utilisation industrielle dans les jus. Certaines propriétés organoleptiques et fonctionnelles du jus d'orange, qui en font un produit attractif pour le consommateur, sont dues à sa composition en caroténoïdes. Les xanthophylles peuvent être trouvés sous leur forme libre (comme on trouve les carotènes) ou sous la forme plus stable d'un acide gras estérifié dans le cas des xanthophylles mono- et polyhydroxylatés. La détection de l'adultération de jus d'orange est préoccupante pour les consommateurs, les organismes de réglementation et les industries de transformation des agrumes, et l'étude de la composition des esters de caroténoïdes a été proposée pour évaluer l'authenticité des produits issus de fruits. Dans ce document, nous présentons les profils des caroténoïdes (esters de caroténoïde et caroténoïdes libres) pour les jus d'orange de huit variétés différentes. Matériel et méthodes. Des jus d'orange frais monovariétaux ont été obtenus à partir d'oranges pressées de mi-saison à partir de huit variétés (Bionda, Brasiliana, Moro, Ovale, Sanguinello, Tarocco, Valence et Washington) cultivées et fournies par un producteur local. Après extraction des caroténoïdes à partir des échantillons, les analyses ont été effectuées par HPLC-DAD-APCI-MS. Résultats et discussion. Les résultats ont montré que, dans les jus étudiés, ce sont surtout les xanthophylles qui ont été estérifiés ( $93 \%$ de la teneur moyenne en caroténoïdes totaux). Les différentes variétés étudiées ont montré des variations dans leur contenu en caroténoïdes. Le contenu total en caroténoïdes a varié de $2,42 \mu \mathrm{g} \cdot \mathrm{g}^{-1}$ pour la variété Washington à $15,8 \mu \mathrm{g} \cdot \mathrm{g}^{-1}$ pour la variété Valencia. Parmi les monoesters, la variété Valencia a montré le plus d'esters violaxanthine (61\%), la variété Brasiliana a eu le plus d'esters $\beta$-cryptoxanthine $(86,9 \%)$ et la variété Tarocco a montré le plus d'esters luteoxanthin $(75,7 \%)$. Par ailleurs, en général, pour les variétés Brasiliana, Ovale, Sanguinello, Valencia et Washington, les teneurs en monoesters ont été plus élevées que les diesters, alors que, dans les variétés Bionda, Moro et Tarocco, c'est le contraire qui a été observé. A notre connaissance, c'est la première fois qu'une telle approche analytique a été appliquée à la caractérisation, à la fois qualitative et quantitative, de toute la structure des caroténoïdes (esters de caroténoïdes et caroténoïdes libres) dans les jus d'orange des variétés Bionda , Brasiliana, Moro, Ovale, Sanguinello, Tarocco, Valence et Washington. Ces résultats pourraient être également utilisés pour établir des marqueurs d'authenticité pour ces variétés d'orange ; leur emploi pourrait permettre de prévenir la falsification.

Italie / Citrus sinensis / fruits / jus d'orange / ester / caroténoïde / xanthophylle / chromatographie 


\section{Introduction}

Among the citrus species, orange has been the most studied given its importance in terms of production and its industrial application in juices. In fact, orange juice is probably the most consumed fruit juice worldwide [1]. Citrus fruits, particularly orange, are commonly regarded as the most complex natural source of carotenoids. Some of orange juice's organoleptic and functional properties, which make it an attractive product for the consumer, are due to its carotenoid composition. Carotenoids are an important kind of natural pigment that can be widely found in plantderived food and products. More than 700 different natural compounds have been described belonging to this group. Although these compounds have been traditionally used in the food industry as colorants, nowadays, they attract great attention since they have been described as possessing several important functional properties, mainly antioxidant activity [2-4], as well as prevention of cardiovascular diseases [5, 6], cancer [7, 8] and macular degeneration $[9,10]$ and, in some cases, provitamin A activity. These properties make these compounds ideal for the always increasing functional food industry as well as promoting the consumption of the natural products in which they are contained.

The chemical structure of carotenoids is usually based in a $\mathrm{C}_{40}$ tetraterpenoid structure with a centrally located, extended conjugated double-bond system which acts as the light-absorbing chromophore and is related to the colour shown [11]. Taking into account their chemical structure, these compounds can be divided into two different groups: firstly, hydrocarbon carotenoids, generally named carotenes; and oxygenated carotenoids, commonly known as xanthophylls. This second group is the most complex one in terms of number of compounds and variations in their structure, and can be found in either its free form (as the carotenes are found) or in a more stable fatty acid esterified form in the case of mono- and polyhydroxylated xanthophylls. Thus, in view of the fact that a single carotenoid could be found forming different esters, the already complex natural variability of carotenoids is often increased by the formation of these carotenoid esters. For this reason, to sim- plify the analysis of these compounds, the most used approach consists of carotenoid analysis after a saponification process. This saponification step allows the release of the carotenoids bound to the fatty acids and their analysis in their free form. Besides, this procedure acts as a clean-up step, eliminating compounds that could interfere in the analysis such as chlorophylls or lipids. In this way the carotenoid composition of citrus [12-14], particularly orange [1, 15-19], among other fruits [3, 20-21], has been extensively studied.

Regarding the carotenoid composition of orange, violaxanthin, luteoxanthin, lutein, $\beta$-cryptoxanthin, antheraxanthin, mutatoxanthin and zeaxanthin have usually been identified as the major carotenoids. However, this approach is not free of drawbacks. In fact, the saponification procedure is well known to produce carotenoid degradation as well as isomerisation and artefact formation, preventing the discerning of the precise native carotenoid composition. In this sense, a different more complex approach could be used, based on the study of the carotenoid ester distribution of the sample as a way of knowing the real native carotenoid composition. Recently, the study of carotenoid esters has been proposed to evaluate fruit product authenticity [22] or even to be used as a ripeness index [23]. Due to the complexity of this task, this approach has been much less used [24] and has been generally aimed at the study of the esters formed by a particular carotenoid. $\beta$-cryptoxanthin esters from different vegetables and fruit [25] as well as astaxanthin esters from different matrices [26, 27], and zeaxanthin esters in plants [28], among others [24, 29], have been studied.

Conventional LC (Liquid Chromatography) has been the technique generally chosen to carry out carotenoid analysis [19]. In particular, since their introduction by Sander et al. [30], $\mathrm{C}_{30}$ stationary phases have been widely employed to this aim. Philip et al. [31] described the determination of carotenoid esters in orange juice, but in their work they carried out a complex sample preparation procedure and different separated analytical steps. Besides, although the particular carotenoid profile of a given orange variety depends to a great extent on genetic and 
environmental factor differences in the carotenoid composition of orange juices, as well as relationships between them, it could be useful to determine their authenticity, and the presence of adulterations as well as the ripeness stage of the fruits used or the age of the juices [32]. In our study we report on the application of a HPLC-DAD-MS (High-Performance-Liquid-Chromatography-DiodeArray-Detector-Mass-Spectrometry) method using $\mathrm{C}_{30}$ stationary phases for the analysis of the carotenoid native composition in eight different varieties of orange juices cultivated in Sicily, Italy. To the best of our knowledge, this is the first time that this methodology has been applied to characterising, both qualitatively and quantitatively, the whole carotenoid pattern (carotenoid esters and free carotenoids) in orange juices from the Bionda, Brasiliana, Moro, Ovale, Sanguinello, Tarocco, Valencia and Washington varieties.

\section{Materials and methods}

\subsection{Samples and chemicals}

Monovarietal fresh orange juices were obtained from squeezing mid-season oranges (Citrus sinensis varieties: Bionda, Brasiliana, Moro, Ovale, Sanguinello, Tarocco, Valencia and Washington) cultivated and supplied by a local producer.

The solvents methanol, methyl tert-butyl ether (MTBE) and water were of HPLC grade and purchased from Sigma-Aldrich (Milan, Italy). Butylated hydroxytoluene (BHT), ethyl acetate and petroleum ether were also obtained from Sigma-Aldrich. Carotenoid standards were purchased from Extrasynthese (Genay, France), or purified in our laboratory using the conventional methods of carotenoid purification [33], and in some cases esterified according to Breithaupt and Bamedi's method [25]. To extract the carotenoids from the samples, the orange juice was treated as described by Schlatterer and Breithaupt [17]. Natural orange juice (80 g) was added to a separation funnel and extracted four times with methanol/ethyl acetate/petroleum ether (1/1/1). The upper phase was kept and ca. $2 \mathrm{mg}$ of BHT were added prior to evaporation under vacuum until dryness. The dry residue was then resuspended in a given volume of MTBE/ methanol (1/1) and stored protected from light at $-18{ }^{\circ} \mathrm{C}$ until use.

\subsection{Instruments and method}

A Shimadzu HPLC instrument (Shimadzu, Milan, Italy) was employed including a SCL10A-VP system controller, two LC-10AD-VP pumps, and a SPD-10Avp diode array detector. A Shimadzu mass spectrometer, LCMS2010, equipped with an APCI interface in the positive ion mode was installed in series. The APCI parameters were set as follows: probe voltage, $4.5 \mathrm{kV}$; probe temperature, $400{ }^{\circ} \mathrm{C}$; block temperature, $200{ }^{\circ} \mathrm{C}$; CDL temperature, $250^{\circ} \mathrm{C}$; Q array voltage, (20 and 80) V; gas flow, $2.5 \mathrm{~L} \cdot \mathrm{min}^{-1}$. Data acquisition and system control were performed by the LCMS solution version 3.30 software (Shimadzu). The injections were done manually through a Rheodyne injection valve (injection volume $20 \mu \mathrm{L}$ ). The $\mathrm{C}_{30}$ column employed consisted of a YMC 30 analytical column (YMC Europe, Schermbeck, Germany) with $5 \mu \mathrm{m}$ $\mathrm{C}_{30} \mathrm{RP}$ material $(250 \mathrm{~mm} \times 4.6 \mathrm{~mm}$ i.d. $)$ including a precolumn (YMC 30; S-5 $\mu \mathrm{m}$, $10 \mathrm{~mm} \times 4.0 \mathrm{~mm}$ i.d.). To carry out the HPLC analyses, an analytical method recently developed at our lab [34] was employed, using methanol/MTBE/water (90:7:3, v/v/ $\mathrm{v}, \mathrm{A})$ and methanol/MTBE (10:90, v/v, B) as mobile phases with gradient elution. The flow rate used was $0.8 \mathrm{~mL} \cdot \mathrm{min}^{-1}$; the chromatograms were recorded from (250 to 600) $\mathrm{nm}$, and the separation temperature was maintained at $23^{\circ} \mathrm{C}$. The APCI-MS (atmospheric-pressure-chemical-ionisationmass spectrometry) instrument was operated in scan mode (positive ionisation) with a m/z range of 200-1200 amu.

\section{Results and discussion}

In studies on the carotenoid composition in natural matrices, there is a general agreement concerning the possibility of finding artefacts as well as isomerisation, rearrangements and underestimation of some carotenoids, after saponification, usually performed to release the carotenoids in their free form and to simplify their analysis. Thus, the study of intact carotenoids' (samples without saponification) composition could 


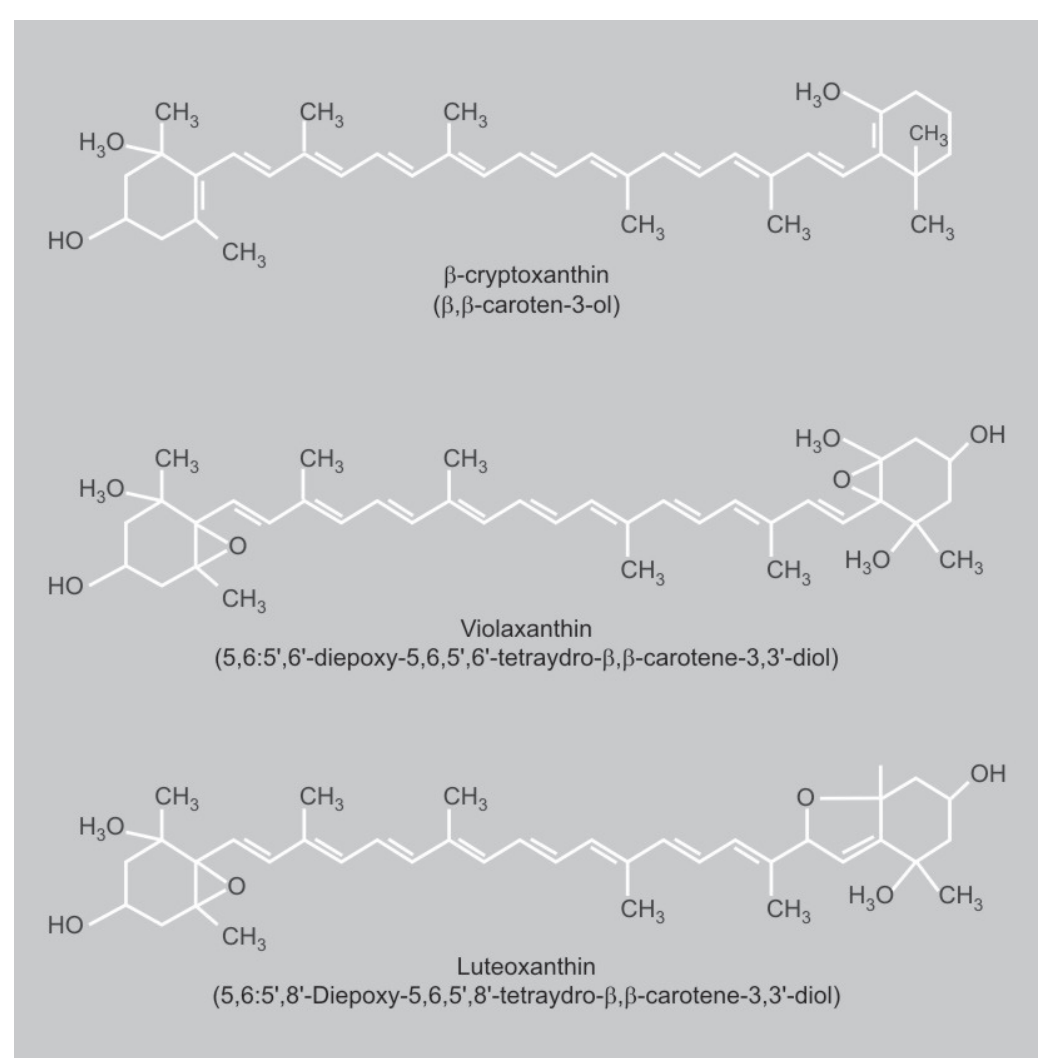

Figure 1.

Chemical structures of $\beta$-cryptoxanthin, violaxanthin and luteoxanthin. characterised in terms of $\mathrm{UV} / \mathrm{Vis}$ and MS spectra and their content in each sample analysed (table I). The identification was carried out by combining the information provided by the two detectors employed (i.e., DAD and MS detectors), the retention times of the available standards, and the identifications previously carried out in our work on the analysis of the native carotenoid composition in orange juice using $\mathrm{C}_{30}$ columns [34] and also in our study on the application of a comprehensive liquid chromatographic method in the separation of epoxycarotenoid esters in orange juices [35]. The quantitative data were obtained by using the method of external standard calibration after the construction of the calibration curves. The coefficient of variation was below $8 \%$ in all measurements and the data were the mean values of three determinations. The results show that, in these juices, the xanthophylls are mostly esterified (93\% of the total carotenoid mean content). Although esterification does not change the visible light absorption properties, esterification increases the solubility of xanthophylls in lipids with which they are associated in nature and this is related to specific objectives for the plants and may also be related to an improvement of the carotenoid bioavailability. Moreover, although esterification does not change the chromophore properties of the carotenoid molecule, it does modify the immediate molecular environment and therefore the chemical activities may be altered depending on the kind of fatty acid bound to the xanthophylls.

The different varieties investigated showed variations in their carotenoid concentrations. The total carotenoid contents ranged from $2.42 \mu \mathrm{g} \cdot \mathrm{g}^{-1}$ in the Washington variety to $15.8 \mu \mathrm{g} \cdot \mathrm{g}^{-1}$ in the Valencia variety (table I); this range is in agreement with Breithaupt et al.'s report on the total carotenoid contents in orange [25] and also in agreement with the report of MelendezMartinez et al. on the Valencia variety, which can be regarded as having one of the highest carotenoid contents among the orange varieties [36]. Among the varieties studied in our work, only the Sanguinello variety showed a total carotenoid content similar to the Valencia variety $\left(14.59 \mu \mathrm{g} \cdot \mathrm{g}^{-1}\right)$. 


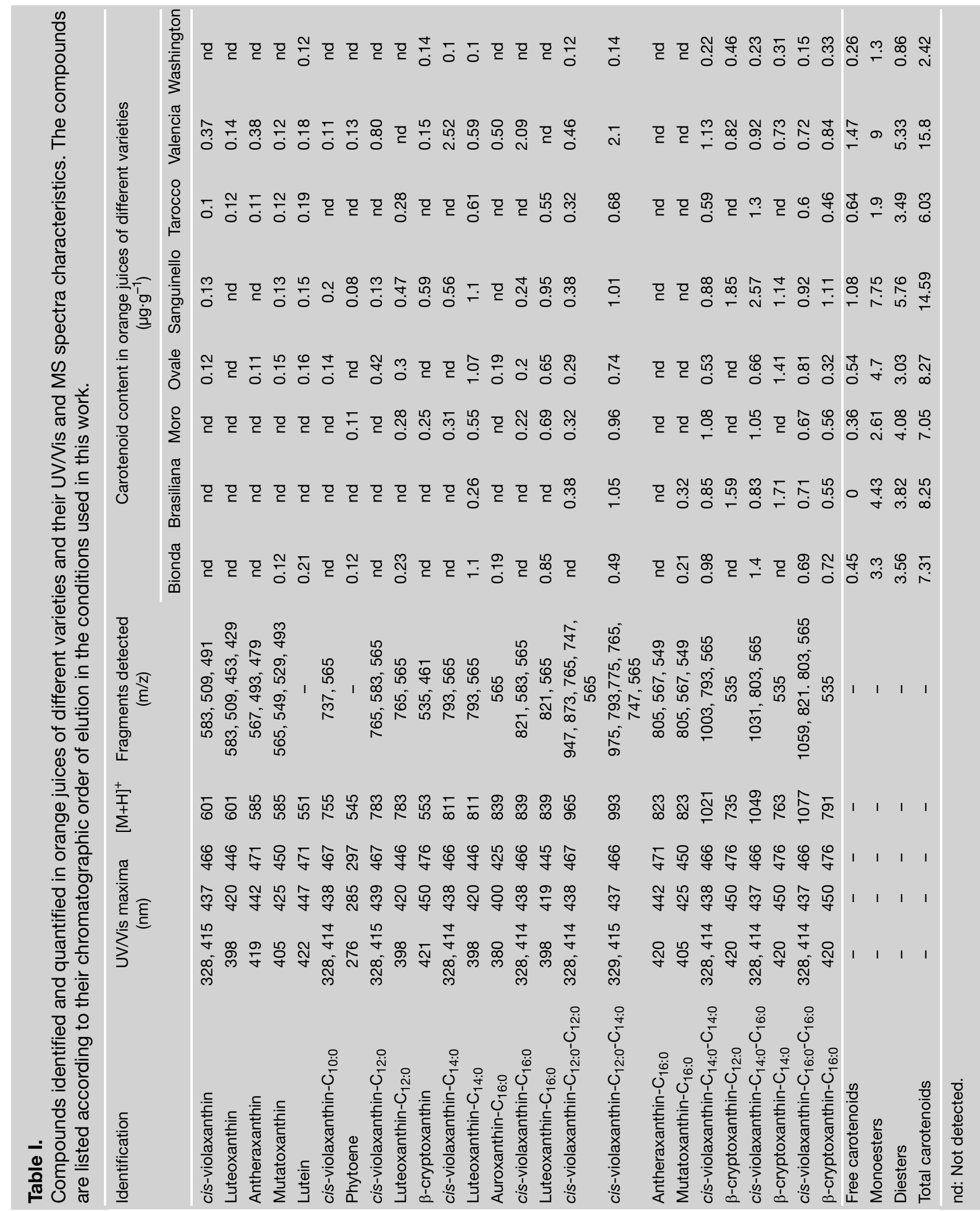


The main carotenoids in the native samples were $\beta$-cryptoxanthin, violaxanthin and luteoxanthin (figure 1), which were mainly present in their more stable mono- and diester forms (table I). The fatty acids esterifing the xanthophylls ranged from $\mathrm{C}_{10}$ to $\mathrm{C}_{16}$. The formation of luteoxanthin is probably due to the acidity of the juice which could be enough to promote the rearrangement of 5,6-epoxides to 5,8-epoxides over time, thus transforming a portion of violaxanthin into luteoxanthin.

In general the total amount of monoesters (50.2\%, mean content) was higher than the total content of diesters $(42.9 \%$, mean content). Among the monoesters, the $\beta$-cryptoxanthin esters were present in the highest amounts. Only diesters of violaxanthin were detected in the samples investigated. Interestingly, among the varieties studied the ester contents were different, showing variability in carotenoid compositions. Among the monoesters, the Valencia variety showed the highest violaxanthin ester amounts (61\%), the Brasiliana variety showed the highest $\beta$-cryptoxanthin ester content (86.9\%) and the Tarocco variety had the highest luteoxanthin ester amount (75.7\%). Moreover, in general, in the Brasiliana, Ovale, Sanguinello, Valencia and Washington varieties, the monoester contents were higher than the diesters', whereas in the Bionda, Moro and Tarocco varieties the opposite was determined. In fact, the mean value for the ratios between the monoester and diester fractions (monoesters/diesters) among the Brasiliana, Ovale, Sanguinello, Valencia and Washington varieties was 1.45 , whereas the mean value for the ratios between the monoester and diester fractions (monoesters/diesters) among the Bionda, Moro and Tarocco varieties was 0.68. As far as the individual compounds quantified in this study are concerned, the cis-violaxanthin-C14:0-C16:0 was the most abundant diester found, reaching the value of $2.57 \mu \mathrm{g} \cdot \mathrm{g}^{-1}$ in the Sanguinello variety, and the cis-violaxanthin-C14:0 and cisviolaxanthin-C16:0 reached the highest amounts among the monoesters in the Valencia variety; respectively, $2.52 \mu \mathrm{g} \cdot \mathrm{g}^{-1}$ and $2.06 \mu \mathrm{g} \cdot \mathrm{g}^{-1}$. These results seem to indicate that myristic (C14:0) and palmitic (C16:0) acids are actively used in the esterification reactions in the samples studied.
The carotenoid profile and contents in fruits and in their juices may depend on several factors such as genetic factors (variety), geographical area, environmental conditions, fruit ripening stage, processing and storage. Different data for the same investigation may also be obtained by the use of different analytical procedures; this should not necessarily be regarded as a negative point, as in fact sometimes complementary information can be obtained. Our present contribution has provided the native carotenoid profile and contents of orange juices from eight different varieties cultivated in Sicily (Italy), showing for the first time the different contents of free, mono- and diesterified carotenoids present in the varieties investigated. This contribution could also be used to establish authenticity markers among orange varieties that could potentially be used to prevent adulteration.

\section{Acknowledgements}

The authors gratefully thank the CRA (Consiglio per la Ricerca e la sperimentazione in Agricoltura) Acireale CT, and the Italian MUIR (Ministero Università Istruzione Ricerca).

\section{References}

[1] Melendez-Martinez A.J., Vicario I.M., Heredia F.J., A routine high-performance liquid chromatography method for carotenoid determination in ultrafrozen orange juices, J. Agric. Food Chem. 51 (2003) 4219-4224.

[2] Leach G., Olivera R., Morais R., Production of a carotenoid-rich product by alginate entrapment and fluid-bed drying of Dunaliella salina, J. Sci. Food Agric. 76 (1998) 298-302.

[3] de Quiros A.R.B., Costa H.S., Analysis of carotenoids in vegetable and plasma samples: A review, J. Food Compos. Anal. 19 (2006) 97-111.

[4] Beutner S., Bloedorn B., Frixel S., Hernandez Blanco I., Hoffman T., Martin H.D., Mayer B., Noack P., Ruck C., Schmidt M., Schulke I., Sell S., Ernst H., Haremza S., Seybold G., Sies H., Stahl W., Walsh R., Quantitative assessment of antioxidant properties of natural colorants and phytochemicals: carotenoids, flavonoids, phenols and indigoids. The role of $\beta$-carotene in antioxidant functions, J. Sci. Food Agric. 81 (2001) 559-568. 
[5] Arab L., Steck S., Lycopene and cardiovascular disease, Am. J. Clin. Nutr. 71 (2000) 1691S-1695S.

[6] Rao A.V., Rao R.G., Carotenoids and human health, Pharm. Res. 55 (2007) 207-216.

[7] Omoni A.O., Aluko R.E., The anti-carcinogenic and anti-atherogenic effects of lycopene: a review macular degeneration, Trends Food Sci. Technol. 16 (2005) 344-350.

[8] Nishino H., Tokuda H., Satomi Y., Masuda M., Bu P., Onozuka M., Yamaguchi S., Okuda Y., Takayasu J., Tsuruta J., Okuda M., Ichiishi E., Murakoshi M., Kato T., Misawa N., Narisawa T., Takasuka N., Yano M., Cancer prevention by carotenoids, Pure Appl. Chem. 12 (1999) 2273-2278.

[9] Snodderly M.D., Evidence for protection against age-related macular degeneration by carotenoids and antioxidant vitamins, Am. J. Clin. Nutr. 62 (1995) S1448-S1461.

[10] Beatty S., Boulton M., Henson D., Koh H.H., Murray I.J., Macular pigment and age-related macular degeneration, Br. J. Ophthalmol. 83 (1999) 867-877.

[11] Melendez-Martinez A.J., Britton G., Vicario I.M., Heredia F.J., Relationship between the colour and the chemical structure of carotenoid pigments, Food Chem. 101 (2007) 1145-1150.

[12] Goodner K.L., Rouseff R.L., Hofsomer H.J., Orange, mandarin and hybrid classification using multivariate statistics based on carotenoid profiles, J. Agric. Food Chem. 49 (2001) 1146-1150.

[13] Agocs A., Nagy V., Szabo Z., Mark L., Ohmacht R., Deli J., Comparative study on the carotenoids composition of the peel and the pulp of different citrus species, Innov. Food Sci. Emerg. Technol. 8 (2007) 390-394.

[14] Matsumoto H., Ikoma Y., Kato M., Kuniga T., Nakagima N., Yoshida T., Quantification of carotenoids in citrus fruit by LC-MS and comparison patterns of seasonal changes for carotenoids among citrus varieties, J. Agric. Food Chem. 55 (2007) 2356-2368.

[15] Rouseff R., Raley L., Application of diode array detection with C-30 reversed phase column for the separation and identification of saponified orange juice carotenoids, J. Agric. Food Chem. 44 (1996) 2176-2181.

[16] Melendez-Martinez A.J., Britton G., Vicario I.M., Heredia F.J., Identification of isolutein (lutein epoxide) as cis-antheroxanthin in orange juice, J. Agric. Food Chem. 53 (2005) 9369-9373.
[17] Schlatterer J., Breithaupt D.E., Cryptoxanthin structural isomers in orange, orange juice, and other fruits, J. Agric. Food Chem. 53 (2005) 6355-6361.

[18] Melendez-Martinez A.J., Vicario I.M., Heredia F.J., Geometrical isomers of violaxanthin in orange juice, Food Chem. 104 (2007) 169175.

[19] Melendez-Martinez A.J., Vicario I.M., Heredia F.J., Analysis of carotenoids in orange juice, J. Food Compos. Anal. 20 (2007) 638-649.

[20] Mendes-Pinto M.M., Silva Ferreira A.C., Oliveira M.B.P.P., Guedes de Pinto P., Evaluation of some carotenoids in grapes by reversed and normal-phase liquid chromatography: a qualitative analysis, J. Agric. Food Chem. 52 (2004) 3182-3188.

[21] De Rosso V.V., Mercadante A.Z., Identification and quantification of carotenoids by HPLC-PDA-MS/MS from Amazonian fruits, J. Agric. Food Chem. 55 (2007) 5062-5072.

[22] Kurz C., Carle R., Shieber A., HPLC-DAD$M^{n}{ }^{n}$ characterisation of carotenoids from apricots and pumpkins for the evaluation of fruit product authenticity, Food Chem. 110 (2008) 522-530.

[23] Hornero-Mendez D., Minguez-Mosquera M.I., Xanthophyll esterification accompanying carotenoid overaccumulation in chromoplast of Capsicum annuum ripening fruits is a constitutive process and useful for ripeness index, J. Agric. Food Chem. 48 (2000) 16171622.

[24] Giuffrida D., La Torre L., Stelitano M., Pellicanò T.M., Dugo G., Application of HPLCAPCI-MS with a C-30 reversed phase column for the characterization of carotenoid esters in mandarin essential oil, Flavour Fragr. J. 21 (2006) 319-323.

[25] Breithaupt D.E., Bamedi A., Carotenoid esters in vegetables and fruits: a screening with emphasis on $\beta$-cryptoxanthin esters, $\mathrm{J}$. Agric. Food Chem. 49 (2001) 2064-2070.

[26] Breithaupt D.E., Identification and quantitation of astaxanthin esters in shrimp (Pandulus borealis) and in microalga (Haematococcus pluvialis) by liquid chromatography-mass spectrometry using negative ion atmospheric pressure chemical ionization, J. Agric. Food Chem. 52 (2004) 3870-3875.

[27] Miao F., Lu D., Li Y., Zeng M., Characterization of astaxanthin esters in Haematococcus pluvialis by liquid-chromatography-atmospheric pressure chemical ionization mass spectrometry, Anal. Biochem. 352 (2006) 176-181. 
[28] Weller P., Breithaupt D.E., Identification and quantification of zeaxanthin esters in plants using liquid chromatography-mass spectrometry, J. Agric. Food Chem. 51 (2003) 7044-7049.

[29] Pott. I., Breithaupt D.E., Carle R., Detection of unusual carotenoid esters in fresh mango (Mangifera indica L. cv. "Kent"), Phytochemistry 64 (2003) 82-829.

[30] Sander L.C., Sharpless K.E., Craft N. E., Wise S.A., Development of engineered stationary phases for the separation of carotenoid isomers, Anal. Chem. 66 (1994) 1667-1674.

[31] Philip T., Chen T.-S., Nelson D.B., Liquid chromatographic profile of major carotenoid esters in commercially processed California navel and Valencia orange juice concentrates, J. Chromatogr. 442 (1988) 249-265.

[32] Perez-Cacho P.R., Rouseff R., Processing and storage effects on orange juice aroma: a review, J. Agric. Food Chem. 56 (2008) 97859796.

[33] Britton G., Liaaen-Jensen S., Pfander H., Carotenoids, Vol. $1 \mathrm{~A}$ : Isolation and analysis, Birkhauser Verlag, Basel, Switz., 1995.

[34] Dugo P., Herrero M., Giuffrida D., Ragonese C., Dugo G., Mondello L., Analysis of native carotenoid composition in orange juice using $\mathrm{C}_{30}$ columns in tandem, J. Sep. Sci. 31 (2008) 2151-2160.

[35] Dugo P., Giuffrida D., Herrero M., Donato P., Mondello L., Epoxycarotenoids esters analysis in intact orange juices using two-dimensional comprehensive liquid chromatography, J. Sep. Sci. 32 (2009), 973-980.

[36] Melendez-Martinez A.J., Vicario I.M., Heredia F.J., Carotenoids, color, and ascorbic acid content of a novel frozen-marketed orange juice, J. Agric. Food Chem. 55 (2007) 13471355.

\section{Composición en carotenoides libres y en ésteres de carotenoides en el zumo de naranja de diferentes variedades.}

Resumen - Introducción. Entre las especies del género Citrus, el más estudiado fue C. senensis, debido a su importancia en términos de producción, y de su aplicación industrial en el zumo. Ciertas propiedades organolépticas y funcionales del zumo de naranja, que lo convierten en un producto atractivo para el consumidor, se deben a su composición en carotenoides. Las xantofilas se pueden encontrar bajo dos modos: bajo su forma libre (como se encuentran los carotenoides), o bajo la forma más estable de un ácido graso esterificado, como en el caso de las xantofilas mono y polihidroxiladas. La detección de la adulteración del zumo de naranja preocupa a consumidores, organismos de reglamentación y a industrias de transformación de los cítricos. Por eso, se propuso estudiar la composición de ésteres de carotenoides y poder evaluar así la autenticidad de los productos derivados de los frutos. En este documento, presentamos los perfiles de carotenoides (ésteres de carotenoides y carotenoides libres) para los zumos de naranja de ocho variedades diferentes. Material y métodos. Se obtuvieron zumos de naranja frescos, monovarietales, a partir de naranjas exprimidas en temporada media, a partir de variedades (Bionda, Brasiliana, Moro, Ovale, Sanguinello, Torocco, Valencia y Washington), cultivados y proporcionados por un productor local. Tras la extracción de los carotenoides a partir de las muestras, se llevaron a cabo análisis mediante HPLC-DAD-APCI-MS. Resultados y discusión. Los resultados mostraron que, en dichos zumos, se esterificaron sobre todo las xantofilas (el 93\% del contenido medio en carotenoides totales). Las diferentes variedades estudiadas mostraron variaciones en su contenido en carotenoides. El contenido total en carotenoides varió desde $2,42 \mu \mathrm{g} \cdot \mathrm{g}^{-1}$, para la variedad Washington, hasta $15,8 \mu \mathrm{g} \cdot \mathrm{g}^{-1}$, para la variedad Valencia. Entre los monoésteres, la variedad Valencia mostró la que más ésteres violaxantina (61\%), la variedad Brasiliana tuvo la que más ésteres $\beta$-criptoxantina (86,9\%); y, la variedad Tarocco mostró la que más ésteres lúteo xantina (75,7\%). Asimismo, en general, para las variedades Brasiliana, Ovale, Sanguinello, Valencia y Washington, los contenidos monoésteres fueron más elevados que los diéteres; mientras que, en las variedades Bionda, Moro y Tarocco, se observó lo contrario. De acuerdo con nuestro conocimiento, es la primera vez que se aplicó un acercamiento de este tipo en las características cualitativas y cuantitativas, de toda la estructura de carotenoides (ésteres de carotenoides y carotenoides libres) en el zumo de naranja de las variedades Bionda, Brasiliana, Moro, Ovale, Sanguinello, Tarocco, Valencia y Washington. Nuestros resultados podrían emplearse asimismo para establecer marcadores de autenticidad de estas variedades de naranjo. Su empleo podría permitir la prevención de su falsificación.

Italia / Citrus sinensis / frutas / zumo de naranja / esteres / carotinoides / xantofilas / cromatografía 